\title{
RELATIONSHIP BETWEEN LINGUISTICS INTELLIGENCE TO LOGICAL-MATHEMATIC INTELLIGENCE IN PUBLIC ELEMENTARY SCHOOL STUDENTS KELURAHAN CIJANTUNG, EAST JAKARTA
}

\author{
Priarti Megawanti* \\ Universitas Indraprasta PGRI \\ Eka Septiani \\ Universitas Indraprasta PGRI \\ Correspondences author: Jl. Asem, Perum. Nuansa Gongseng No. 6, Kota Jakarta Timur, Kode Pos: 13770, Indonesia; \\ e-mail: priartimegawanti@gmail.com
}

\begin{abstract}
For those who studied ang studying mathematics, are often labeled with a tendency to be stiff and few words, less creative, even minus the imaginative. In fact, someone who is great in numbers actually able to understand the nature and can solve the daily problems. That is because mathematics is actually more than just the science of counting numbers and memorizing formulas, but the science that simplifies the universe into numbers and formulas. The ability to solve mathematical problems cannot be separated from language skills. Language skills will help someone to understand mathematical language that uses a combination of numbers, letters, and symbols. That way, it is very interesting to know whether language ability has a relationship with one's mathematical ability. Simple linear regression test showed that there is a significant influence between language intelligence and mathematical intelligence. The results of the analysis for simple correlation (Product Moment) showed a significant positive correlation between language intelligence and mathematical intelligence. The coefficient of determination is obtained at $44.021 \%$, which means that Language Intelligence affects Mathematical Intelligence as much as $44,021 \%$. Students who have language intelligence will more easily understand mathematical problems, because in answering a mathematical problem, one must be able to know the purpose of the problem first. Because mathematics uses a combination of numbers, letters, and symbols, it is very important for someone who wants to master mathematics to understand the meaning and purpose of language. Logically, someone who has language intelligence has a curiosity to find out the implicit meaning of what he is learning. He tends not only to memorize the formula but try to understand it. At the stage of being able to understand a language, someone will more easily understand the purpose of the problem and answer it correctly.
\end{abstract}

Key Words: intelligence, language, mathematical.

Article History: Received: 22/09/2019; Revised: 20/10/2019; Accepted: 18/11/2019; Published: 31/12/2019

How to Cite (MLA 7th): Megawanti, Priarti dan Septiani, Eka. "Relationship between Linguistics Intelligence to Logical-Mathematic Intelligence in Public Elementary School Students Kelurahan Cijantung, East Jakarta ." Hortatori Jurnal Pendidikan Bahasa dan Sastra Indonesia vol.no (2019): 118-124. Print/Online. Copyrights Holder: Megawanti, Priarti dan Septiani, Eka. First Publication: Hortatori Jurnal Pendidikan Bahasa dan Sastra Indonesia (2019).

This work is licensed under a Creative Commons Attribution-ShareAlike 4.0 International License.

\section{Pendahuluan}

Banyak orang yang meyakini bahwa seseorang yang ahli di bidang hitung menghitung, biasanya mengalami kesulitan dalam berbahasa. Keyakinan tersebut dapat kita sebut mitos, alias belum dapat dibuktikan secara ilmiah kebenarannya. Dikatakan mitos, karena secara ilmu neurologi, terutama pada bagian belahan otak atau hemisphere, diketahui bahwa kemampuan berbahasa dan kemampuan matematis 
berada pada hemisphere otak yang sama, yaitu sebelah kiri. Hal tersebut diperkuat oleh Sawega (2005: 157) dalam artikelnya yang menyatakan bahwa belahan otak kiri memiliki fungsi proposisi verballinguistis, logis, analitis. Spesialisasinya berkaitan dengan kemampuan verbal, berbicara, dan berbahasa. Termasuk kemampuan mengeja, menulis, dan menghitung, serta mengingat-ingat fakta dan nama. Berdasarkan pernyataan Sawega tersebut, seseorang yang menguasai bahasa seharusnya juga akan mudah menguasai matematika. Itu dikarenakan kemampuan bahasa dan logis-matematis sama-sama bekerja di belahan otak kiri. Lantas apa yang membuat seseorang yang pandai dalam matematika, terkadang sulit mengungkapkan sesuatu dengan tulisan atau perkataan? Untuk mengetahui jawabannya, maka perlu untuk meneliti terlebih dahulu perihal hubungan kecerdasan matematis dengan kecerdasan linguistik. Jika secara ilmu otak, keduanya memiliki kemampuan yang sama dalam hal kelogisan, seharusnya secara realita terdapat kesesuaian antara kedua kecerdasan ini.

Sunario (1994) dalam Julianto (2003: 19) menyatakan bahwa otak manusia terdiri atas belahan otak (hemisphere) kiri dan kanan. Otak kiri manusia melakukan pendekatan pemecahan masalah berdasarkan fakta, analisis, tahap demi tahap, perhitungan angka-angka, dan menyatakannya dengan menunjukkan fakta disertai urutan yang logis. Sementara otak kanan berdasarkan pada spontanitas apa yang ada dalam pikiran, imanjinasi, bentuk, suara dan gerakan, dan dikonsepkan dalam intuisinya. Berdasarkan pembagian kerja dan perbedaan fungsi dari kedua belahan otak tersebut, maka sesungguhnya kecerdasan logis-matematis dan bahasa bekerja dan diolah pada belahan otak yang sama. Hanya saja, dalam berbahasa, terkadang membutuhkan kemampuan berimajinasi dalam membayangkan kata-kata dan bahasa apa yang tepat dipakai oleh seseorang untuk menyampaikan sebuah pesan. Seseorang perlu untuk membayangkan bagaimana mengungkapkan apa yang dia pikiran atau rasakan melalui kata-kata yang tepat, itulah yang kemudian menjelaskan kenapa menjawab soal berbentuk esai cenderung lebih sulit dibandingkan mengerjakan soal hitungan. Menjawab soal esai membutuhkan bantuan belahan otak kanan untuk mendeskripsikan sesuatu dengan kata-kata yang tepat. Sebenarnya imajinasi juga dibutuhkan dalam memecahkan soal matematika. Dengan begitu, secara teori belahan otak, kemampuan logis-matematis dan bahasa membutuhkan kapasitas belahan otak yang sama, yaitu kiri dan kanan. Pada dasarnya, otak tidak dapat bekerja parsial atau terpisah, melainkan bekerjasama dan bersinergi antara kedua belahan otak kanan dan kiri. Sunario menambahkan, bahwa dalam persoalan kreativitas, seseorang tidak bisa membatasi kemampuannya pada bidang seni saja. Dalam bidang matematika dan bahasa, seseorang juga perlu berkreativitas (Pudjiastuti, 2005: 170).

Kenyataan yang ditemukan di lapangan adalah pada anak usia Sekolah Dasar (SD), terutama peserta didik kelas VI yang akan menghadapi Ujian Nasional (UN), bahwa mereka lebih menyukai pelajaran yang logis dan berpola sama, seperti matematika. Mereka cenderung kurang meminati pelajaran yang lebih banyak menghafal dan membutuhkan kemampuan membayangkan yang abstrak, seperti pelajaran Bahasa Indonesia dan Ilmu Pengetahuan Sosial (IPS). Pada pelajaran Ilmu Pengetahuan Alam (IPA), beberapa peserta didik SD ada yang menyukainya, dikarenakan pelajaran ini membahas tentang alam yang dapat mereka lihat secara konkret di sekitar mereka. Berbeda dengan pelajaran Bahasa Indonesia. Pelajaran ini dianggap lebih menyulitkan dibanding matematika dikarenakan membutuhkan kejelian dalam penggunaan kata-katanya. Terkadang, faktor menyepelekan dan menganggap mudah menjadi salah satu penyebab rendahnya nilai UN pelajaran yang berisikan penulisan Ejaan Yang Disempurnakan (EYD), bahasa baku dan tidak baku, imbuhan, majas, prosa, puisi, pantun, dan lain-lain ini.

Menurut Muzaqi (2008: 133) kesenangan terhadap matematika harus dimunculkan sejak dini. Muzaqi mengutip Mosley dan Meredith bahwa pengenalan matematika sejak dini diyakini akan membantu memperkuat intelektualitas anak di sekolah (2008: 133). Pengenalan pelajaran matematika yang baik, akan membantu peserta didik memiliki persepsi positif tentang matematika. Selain matematika, kemampuan berbahasa yang mencakup kemampuan membaca, mendengar, menulis, dan berbicara juga perlu dikembangkan sejak dini.

Kecerdasan menurut Gardner (2013: 18-19) adalah kompetensi kognitif manusia yang dipadupadankan dengan keahlian, bakat, atau kemampuan mental. Gardner meyakini bahwa setiap manusia normal memiliki keahliannya masing-masing hingga taraf tertentu dan kombinasi dengan keahlian lainnya. Gardner juga menyatakan bahwa kecerdasan merupakan kemampuan komputasi kemampuan untuk memproses jenis informasi tertentu - yang berasal dari faktor biologis dan psikologis manusia. 
Seperti halnya kecerdasan logis, para ahli menyebut keahlian linguistik sebagai kecerdasan. Hal tersebut sepandangan dengan pandangan umum yang mengukur kecerdasan hanya dari kecerdasan kognitif. Dalam otak manusia, terdapat wilayah otak yang disebut wilayah Broca. Wilayah Broca tersebut bertanggung jawab atas produksi kalimat gramatikal seseorang. Bakat berbahasa itu merupakan kecerdasan yang universal atau umum dimiliki oleh siapapun, tanpa mengacu kepada tingkat pendidikan atau latar belakang sosial-ekonomi seseorang. Perkembangan berbahasa yang cepat serta nonproblematis, dialami oleh sebagian besar anak dari berbagai latar belakang budaya. Bahkan pada populasi tuna rungu, dimana bahasa isyarat tidak diajarkan secara eksplisit, namun anak-anak tuna rungu tersebut menemukan bahasa manual mereka sendiri dengan mengunakan dan menyepakatinya secara terbatas dan diam-diam. Oleh karena itu, Gardner melihat bahwa kecerdasan linguistik atau berbahasa merupakan modal kecerdasan yang mudah untuk dipelajari dan dikuasai siapapun (Gardner, 2013: 26-27).

Sependapat dengan pernyataan Gardner, Armstrong (2003: 19) menyatakan bahwa kecerdasan berbahasa atau linguistik adalah kemampuan menggunakan kata-kata secara efektif. Pengamatan terhadap 3M (membaca, menulis, matematika) dalam kehidupan sekolah memperlihatkan bahwa kecerdasan linguistik mencakup sedikitnya dua pertiga bagian dari interaksi belajar-mengajar yang mencakup sebagian banyak dengan membaca dan menulis. Di dalam kegiatan membaca dan menulis tersebut, terdapat cakupan luas dari kemampuan linguistik, termasuk mengeja, kosakata dan tata bahasa. Kecerdasan berbahasa juga erat kaitannya dengan kemampuan berbicara. Kecedasan ini amat diperlukan dalam keseharian manusia seperti berbicara, mendengarkan, membaca apa pun mulai dari rambu lalu lintas sampai novel klasik, dan menulis apa pun mulai dari pesan sederhana sampai laporan kantor.

Sunario mengutip pendapat Gardner yang menyatakan bahwa kemampuan bahasa atau linguistik merupakan kemampuan dasar yang setiap orang miliki. Di sini kemampuan seseorang dalam mengolah kata, terus menerus dituntut untuk berkembang, terlebih dengan bertambahnya usia seseorang. Kemampuan berbahasa umumnya tak menjadi masalah baik di sekolah maupun di luar sekolah. Hanya saja, seseorang yang berusia dewasa, jika tidak mengasah kemampuan berbahasanya, akan mengalami kesulitan dalam beragumentasi dan melakukan proses persuasif. Dimana kemampuan berargumen dan berlaku persuade ke arah positif, sangat dibutuhkan dalam dunia kerja, bermasyarakat, dan kehidupan pribadi. Menurut Sunario seseorang yang melatih dan meningkatkan kemampuan bahasanya, akan bisa beragumentasi dengan menarik dan persuasif (Pudjiastuti, 2005: 168).

Armstrong (2003: 25) memaparkan bahwa seseorang dengan kecerdasan bahasa memiliki keterampilan pendengaran yang sangat berkembang dan menyukai bermain dengan bunyi bahasa dan kata-kata seperti pantun, lirik yang berima, atau hal-hal kecil. Mereka sering berpikir dalam kata-kata. Mereka sering asyik membaca atau sibuk menulis cerita atau puisi. Meski seandainya mereka tidak menyukai membaca atau menulis, biasanya mereka seorang penutur cerita yang berbakat. Seseorang dengan kecerdasan ini sangat mungkin akan menyukai pekerjaan menjadi seorang penulis, sekretaris, penyunting, ilmuwan sosial, guru humaniora, atau politisi. Mereka cepat belajar dengan menggunakan kata-kata, atau hanya dengan mendengar dan melihat kata-kata tersebut.

Gardner dalam bukunya - Multiple Intelligence - memberikan satu contoh mengenai seseorang yang memiliki kecerdasan logis matematis. Berdasarkan contoh tersebut, Gardner memberikan suatu simpulan bahwa seseorang dengan kecerdasan logis-matematis yang dominan memiliki kemampuan memecahkan masalah yang luar biasa cepat. Hanya saja, tidak semua orang mampu memahami bahasa angka dalam upaya menyelesaikan masalah yang dilakukan individu dengan kecerdasan ini. Oleh karenanya, bersama dengan kecerdasan berbahasa (linguistik) kedua kecerdasan ini menjadi salah satu indikator utama bagi para psikolog konvensional untuk mengukur kecerdasan individu (Gardner, 2013: 25-26).

Kecerdasan logis-matematis melibatkan keterampilan mengolah angka dan atau kemahiran menggunakan logika atau akal sehat. Ini adalah kecerdasan yang digunakan ilmuwan ketika menciptakan hipotesis dan mengujinya dengan data eksperimental. Kecerdasan ini juga diperlukan bagi seseorang untuk mengecek tagihan, mengatur keuangan rumah tangga atau perusahaan, dan lain-lain yang berkaitan dengan hitung menghitung. Walaupun beberapa orang mengalami kesulitan ketika berhadapan dengan angka-angka yang banyak dan seringnya abstrak, namun kecerdasan ini sangat penting untuk dikuasai (Armstrong, 2003: 20).

Setelah kecerdasan bahasa, menurut Sunario yang mengutip Gardner, kemampuan kedua dari kecerdasan majemuk adalah kecerdasan logis-matematis. Kecerdasan atau kemampuan ini mencakup 
rasionalitas, mengurutkan kejadian atau menarik hubungan antara simbol yang satu dengan lainnya, dan memikirkan sesuatu berdasarkan sebab akibatnya (Pudjiastuti, 2005: 168).

Armstrong (2003: 26) menyatakan bahwa seseorang dengan kecerdasan ini berpikir secara numerik atau dalam konteks pola serta urutan logis, atau dalam bentuk-bentuk cara berpikir logis yang lain. Asmtrong menyebutkan bahwa seseorang yang memiliki kecerdasan logis matematis biasanya saat remaja mampu memikirkan sesuatu hal logis secara abstrak. Mereka ini adalah seseorang yang selalu ingin tahu dan selalu ingin mendapatkan jawaban tentang peristiwa alam. Mereka suka dengan tantangan yang membutuhkan strategi dan pemikiran yang rumit. Biasanya, seseorang dengan kecerdasan ini akan menyukai berprofesi sebagai ilmuwan, insinyur, pemrogram komputer, akuntan, atau mungkin guru. Berdasarkan penjelasan teori-teori di atas mengenai kecerdasan matematika, maka kecerdasan ini merupakan kecerdasan yang umumnya dimiliki oleh semua orang, walaupun dengan tingkat kemampuan yang berbeda-beda. Setiap orang, baik disadari atau tidak, menggunakan kecerdasan ini dalam menyelesaikan permasalahan yang terkait dengan logis-matematika setiap harinya.

Penelitian ini pada dasarnya berguna untuk menjawab rasa ingin tahu peneliti, dikarenakan antara teori dan kenyataan berbeda. Untuk itu penelitian ini diharapkan dapat menjelaskan faktor-faktor apa yang membuat antara teori dengan kenyataan tak sesuai. Selain untuk memenuhi rasa ingin tahu peneliti, diharapkan hasil penelitian ini dapat membantu peserta didik atau pun mahasiswa yang menyukai matematika untuk mencari tahu penyebab dan solusi sulitnya mengutarakan dan menginterpretasikan jawaban, berupa angka dari permasalahan yang berhasil dipecahkan, dengan menggunakan kata-kata. Hasil penelitian ini diharapkan juga dapat membantu pendidik untuk memberikan informasi berharga bagi peserta didiknya dengan menjelaskan angka dan rumus matematika secara lebih bermakna, konkret, dan bermanfaat dalam hidup mereka.

\section{Metode}

Metode penelitian yang digunakan dalam penelitian ini adalah metode survei dengan analisis regresi dan korelasi sederhana. Data penelitian ini diperoleh dari hasil nilai Try Out Ujian Nasional (UN) untuk mata pelajaran Bahasa Indonesia dan Matematika kelas. Variabel yang diteliti pada penelitian ini ada dua, yaitu (1) kecerdasan bahasa (linguistik) sebagai variabel yang mempengaruhi dan (2) kecerdasan logis-matematis sebagai variabel yang dipengaruhi.

Menurut Palte (1978) dalam Mantra dan Kasto (1995: 152) terdapat dua macam populasi, yaitu populasi sampling dan populasi sasaran. Populasi sampling adalah seluruh individu yang terdapat dalam lingkup penelitian. Pada penelitian ini yang termasuk sebagai populasi sampling adalah seluruh peserta didik yang duduk di bangku kelas VI SDN di Kelurahan Cijantung, Jakarta Timur.

Penentuan sampel dilakukan dengan metode simple random sampling atau sampel acak sederhana. Tiap-tiap responden yang masuk ke dalam populasi sasaran memiliki kesempatan yang sama untuk dipilih sebagai sampel. Alasan menggunakan metode tersebut adalah karena sifat populasi yang homogen dan tidak terlalu tersebar secara geografis. Homogen di sini dilihat dari tingkat pendidikan yang rata-rata adalah peserta didik yang duduk di bangku kelas VI SD, dengan rentang usia dari 10-13 tahun, dan lokasi tempat tinggal di sekitar Kelurahan Cijantung, Jakarta Timur.

Tempat penelitian adalah di Sekolah Dasar Negeri (SDN) Kelurahan Cijantung, Jakarta Timur. SDN di Kelurahan Cijantung terdiri atas SDN 01, 02, 03, 05, 06, 07, dan 09. Dari 7 sekolah tersebut, hanya 3 sekolah yang merespon positif dan bersedia bekerjasama untuk memberikan data penelitian. Sekolah tersebut adalah SDN 01, 05, dan 06 Cijantung. Alasan memilih SDN di kelurahan Cijantung dikarenakan lokasinya mudah diakses, sehingga dapat mengatasi permasalahan dalam hal keterbatasan waktu, dana, dan tenaga pada penelitian ini.

Teknik pengumpulan data dilakukan berdasarkan pada jenis data yang hendak didapatkan. Pengumpulan data primer dilakukan dengan mengumpulkan hasil nilai try out Ujian Nasional kelas VI. Pengumpulan data sekunder dilakukan dengan penelusuran literatur berupa buku, artikel, jurnal, dan lainlain.

\section{Hasil dan Diskusi}

Pengumpulan data dilakukan dengan jumlah sampel sebanyak 126 responden yang merupakan peserta didik kelas VI dari SDN 01, 05, dan 06 Cijantung di Kelurahan Cijantung, Jakarta Timur. Berdasarkan data yang telah dikumpulkan, maka dilakukan uji linier regresi sederhana untuk mencari dan menguji persamaan regresi variabel terikat atas variabel bebas. Persamaan regresi yang dimaksud adalah 
persamaan regresi variabel Kecerdasan Logis Matematis (Y) atas Kecerdasan Bahasa (Linguistik) (X). Perhitungan uji linieritas menghasilkan regresi Kecerdasan Matematika atas Kecerdasan Bahasa, dimana $F_{\text {hitung }}=0,886$ dan $F_{\text {tabel }}=1,539$. Oleh karena $F_{\text {hitung }}<F_{\text {tabel }}$, maka dapat disimpulkan bahwa model regresi berpola linier. Sementara hasil uji regresi linier sederhana menghasilkan $F_{\text {hitung }}=97,510$ dan $F_{\text {tabel }}=3,918$. Oleh karena kriteria $F_{\text {hitung }}>\mathrm{F}_{\text {tabel}}$, maka disimpulkan bahwa terdapat pengaruh yang signifikan antara Kecerdasan Bahasa dengan Kecerdasan Matematika.

Uji berikutnya yaitu uji korelasi sederhana. Uji ini untuk mengetahui hubungan antara variabel bebas dan variabel terikat. Sementara hasil analisis untuk korelasi sederhana (Product Moment) menunjukkan koefisien korelasi dengan $r_{x y}=0,663$ dan $r_{\text {tabel }}=0,174$. Oleh karena $r_{x y}>r_{\text {tabel }}=0,663>$ 0,174, maka dapat dikatakan bahwa terdapat korelasi positif yang signifikan antara Kecerdasan Bahasa dengan Kecerdasan Matematika. Dari hasil tersebut didapatkan Koefisien Determinasi atau KD sebesar 44,021\%, yang artinya Kecerdasan Bahasa memengaruhi Kecerdasan Matematika sebanyak 44, $021 \%$. Sisanya, sebanyak 55,979\% dipengaruhi oleh faktor lain.

Berdasarkan hasil perhitungan di atas, menunjukkan bahwa ada hubungan antara Kecerdasan Bahasa dengan Kecerdasan Matematika. Hal tersebut dapat dijelaskan bahwa peserta didik yang memiliki Kecerdasan Bahasa akan lebih mudah memahami soal matematika. Dalam menjawab suatu soal matematika, seseorang harus dapat mengetahui dulu maksud dari soal tersebut. Oleh karena matematika menggunakan perpaduan bahasa angka, huruf, dan simbol, maka penting sekali bagi seseorang yang ingin menguasai matematika untuk mengerti arti dan maksud dari bahasa.

Seseorang atau peserta didik yang mampu memahami maksud dari soal matematika, akan mampu menjawab soal dengan langkah yang tepat. Seseorang atau peserta didik yang tidak mampu memahami maksud dari soal matematika, akan mengalami kesulitan menjawab dan memecahkan soal tersebut, walaupun soal matematika itu digolongkan kepada soal yang mudah. Jusyak (2005: 126 - 130) menjelaskan dalam artikelnya secara gamblang mengenai pentingnya logika bahasa bagi anak. Ia menyatakan bahwa kemajuan teknologi sekarang ini, seharusnya justru semakin mendorong seseorang untuk menguasai logika bahasa yang baik. Ia menyatakan bahwa untuk menguasai berbagai macam ilmu pengetahuan, kemampuan bahasa memegang peranan yang sangat penting. Ilmu Pengetahuan dan Teknologi (IPTEK) tidak bisa dikuasai tanpa kemampuan bahasa yang baik. Jusyak menambahkan bahwa bahasa membantu seseorang memperhalus dan memperluas pengetahuannya tentang dunia, memudahkannya mendapatkan informasi baru, dan membantunya menyimpan informasi yang telah dipelajari, dimana kesemua itu akan berujung kepada kemampuan memecahkan persoalan. Dengan kata lain, bahasa merupakan perangkat utama komunikasi atau kunci untuk menguasai aspek-aspek lain dalam hidup. Dalam kaitannya dengan matematika, Jusyak menegaskan bahwa jika kemampuan bahasa seseorang baik, maka logika matematikanya pun baik. Hal tersebut tidak berlaku kebalikannya.

Matematika sebenarnya bukan mata pelajaran yang sekedar mempelajari tentang angka dan rumus, tetapi matematika mempelajari bagaimana seseorang dapat memecahkan masalahnya sehari-hari dan bagaimana seseorang bisa menemukan solusi dari situasi yang dia hadapi. Apabila manusia secara teliti mengamati, maka yang ada di sekelilingnya terkait erat dengan matematika dan manusia setiap harinya dituntut untuk mengerjakan soal matematika. Matematika yang ada di alam semesta memang tidak berbentuk angka dan rumus, tetapi para ahli matematika menemukan cara untuk menyederhanakan alam semesta ke dalam sebuah angka atau pola bilangan dan rumus. Rumus dan pola bilangan itulah yang kemudian dipelajari oleh peserta didik di bangku sekolah maupun mahasiswa di bangku kuliah. Hanya saja, mereka seringkali kesulitan menemukan apa maksud dari angka, pola bilangan, dan rumus yang mereka pelajari itu. Dengan demikian, apabila seseorang mempelajari matematika hanya sebatas untuk memenuhi tugas dari guru atau dosen, maka ia akan mengalami kebuntuan dan kemonotonan dalam mempelajari matematika.

Kebuntuan dan kemonotonan akibat mempelajari matematika sekedar menghafal pola bilangan, angka, dan rumus, mengakibatkan peserta didik atau mahasiswa kesulitan dalam menginterpretasikan arti dan maksud dari pola bilangan, angka, dan rumus yang mereka pelajari. Akibatnya, walaupun mereka pintar secara teori tetapi gagal memahami bahasa matematika, maka ketika mereka menemukan masalah di dalam kehidupannya, mereka tak akan terpikirkan untuk menggunakan kecerdasan matematika yang mereka miliki untuk mencari solusi permasalahan.

Secara logika, seseorang yang memiliki Kecerdasan Bahasa, memiliki rasa ingin tahu untuk mengetahui arti implisit dari apa yang ia pelajari. Ia cenderung tidak hanya sekedar menghafal rumus 
tetapi mencoba untuk memahaminya. Rasa ingin tahu dan upaya untuk memahami tersebut akan membedakan seseorang yang mempelajari matematika tanpa mencoba memahami maksud tersembunyi dari pola bilangan, angka, dan rumus dalam matematika. Pada tahap mampu memahami suatu bahasa, seseorang akan lebih mudah memahami maksud soal dan menjawabnya dengan tepat. Disinilah mengapa seseorang perlu mempelajari bahasa, dengan banyak membaca, perbendaharaan kata dan wawasan akan semakin banyak. Perbendaharaan kata dan wawasan yang banyak akan memacu seseorang untuk lebih memahami bentuk bahasa. Subiyanto (2007) memaparkan dalam skripsinya bahwa jika kecerdasan verbal lebih mengarah pada ranah bahasa yang digunakan dalam soal cerita. Demikian juga dengan kecerdasan logika-matematika yang digunakan ketika melakukan perhitungan, berhubungan dengan angka-angka matematika. Siswa dapat mengubah soal cerita menjadi bentuk pola logis beserta hubunganhubungannya. Hal tersebut dapat dilakukan dengan melakukan pengurutan, pengelompokan, dan perhitungan.

Jusyak (2015: 130) memberikan simpulan di akhir artikelnya, yaitu: "Ingat, logika bahasa yang baik, menjadi jembatan bagi berkembangnya kecerdasan anak untuk menjadi anak yang mampu menyesuaikan diri dengan lingkungannya di masa datang". Asumsinya, seseorang yang memiliki Kecerdasan Bahasa akan memiliki Kecerdasan Matematika. Hal itu yang terbukti dalam penelitian ini.

Pada penelitian ini, terdapat keterbatasan dan kekurangan. Oleh karena data didapatkan dari hasil try out UN yang isi soal beragam dari tiap-tiap sekolah, maka hal tersebut mengakibatkan kerancuan apakah memang hasil nilai didapatkan dari soal yang memiliki tingkat kesulitan ataupun kemudahan yang sama. Selain itu, oleh karena peneliti tidak hadir saat sampel mengerjakan try out UN, maka apakah hasil yang didapat adalah murni atau tidak atau bahkan mungkin ada siswa yang mengerjalan dengan asal tebak, tidak dapat diketahui secara pasti. Selain itu, rencana awal sekolah yang akan dimintai data berjumlah 8 SDN dengan tujuan agar dapat memberi gambaran hasil penelitian secara lebih jelas, pada kenyataannya hanya tiga SDN yang bersedia memberikan data nilai try out UN tersebut.

\section{Simpulan}

Berdasarkan hasil uji regresi linier sederhana menghasilkan Fhitung $=$ 97,510 dan Ftabel $=3,918$. Oleh karena jika Fhitung > Ftabel, maka disimpulkan bahwa terdapat pengaruh yang signifikan antara Kecerdasan Bahasa dengan Kecerdasan Matematika. Hasil analisis untuk korelasi sederhana (Product Moment) menunjukkan rxy > rtabel, 0,663 > 0,174, maka dapat dikatakan bahwa terdapat korelasi positif yang signifikan antara Kecerdasan Bahasa dengan Kecerdasan Matematika. Dimana didapatkan koefisien determinasi atau KD sebesar 44,021\%, yang artinya Kecerdasan Bahasa mempengaruhi Kecerdasan Matematika sebanyak 44, $021 \%$.

\section{Ucapan Terima Kasih}

Kami haturkan terimakasih atas bantuan dan kerjasama Kepala SDN 01 Cijantung, SDN Cijantung SDN 05 Cijantung, dan SDN 06 Cijantung, sehingga Kami dapat melakukan perhitungan dan menyelesaikan penelitian ini.

\section{Daftar Rujukan / References}

Armstrong, Thomas. Setiap Anak Cerdas!. Jakarta: Gramedia Pustaka Utama. 2003.

Gardner, Howard. 2013. Multiple Intelligences - Memaksimalkan Potensi dan Kecerdasan Individu dari Masa Kanak-kanak Hingga Dewasa. Jakarta: Daras Books.

Julianto, Irwan. 2003. Memahami Dua Belahan dan Empat Kuadran Otak. dalam Memahami Otak. Jakarta: Penerbit Buku Kompas.

Jusyak, Kunadi. Pentingnya Logika Bahasa bagi Anak. dalam Mencetak Anak Cerdas dan Kreatif. Jakarta: Penerbit Buku Kompas. 2005.

Mantra, Ida Bagoes dan Kasto. Penentuan Sampel. dalam Metode Penelitian Survai. Jakarta: LP3ES. 1995.

Muzaqi, Moh. Penerapan Kompetensi Pedagogis Tenaga Pendidik PAUD pada Pencapaian Perkembangan Bahasa dan Matematika Anak Usia Dini. dalam Jurnal Ilmiah Visi.Volume 3, No. 2 - 2008. Universitas Negeri Jakarta. 2008. 
124 Relationship between Linguistics Intelligence to Logical-Mathematic Intelligence in Public Elementary School Students Kelurahan Cijantung, East Jakarta Judul Artikel

Pudjiastuti, Chris. Kenali Tujuh Kemampuan Diri. dalam Mencetak Anak Cerdas dan Kreatif. Jakarta: Penerbit Buku Kompas. 2005.

Sawega, M. Ardus. Pendidikan Kesenian Menyeimbangkan Fungsi Otak. dalam Mencetak Anak Cerdas dan Keatif. Jakarta: Penerbit Buku Kompas. 2005

Subariyanto, Muhammad Isro'i. Hubungan antara Kecerdasan Verbal dan Kecerdasan LogikaMatematika dengan Kemampuan Menyelesaikan Soal Cerita Matematika Siswa Kelas V SD Negeri 8 Metro Timur Tahun Pelajaran 2016-2017. Skripsi: Universitas Lampung (tidak diterbitkan). 2007. 